\title{
Banking Relationships, Managerial Ownership and Operational Performance: A Simultaneous Equations Approach in the Context of SMEs
}

\author{
Mário Gomes Augusto ${ }^{1} \&$ António Pedro Soares Pinto ${ }^{2}$ \\ ${ }^{1}$ School of Economics and Institute of Systems and Robotics, University of Coimbra, Coimbra, Portugal \\ ${ }^{2}$ Polytechnic Institute of Viseu, Viseu, Portugal \\ Correspondence: Mário Gomes Augusto, School of Economics and Institute of Systems and Robotics, University of \\ Coimbra, Avenida Dias da Silva, 165, 3004-512 Coimbra, Portugal. Tel: 351-2-3979-0544. E-mail: \\ maugusto@fe.uc.pt
}

Received: September 22, 2014

doi:10.5430/ijfr.v6n1p22
Accepted: October 16, 2014

Online Published: November 4, 2014

URL: http://dx.doi.org/10.5430/ijfr.v6n1p22

\begin{abstract}
This paper provides new evidence for the relationship between the nature of banking relationships, managerial ownership and operational performance in supporting reciprocal effects between these variables in the context of small and medium enterprises (SMEs). A simultaneous equations model was applied to a sample of 4,163 Portuguese SMEs and to cross-section data. Evidence was found that these attributes provide simultaneous relations among themselves. In particular, on the one hand, our results support a negative effect of the number of banks with which the company works and managerial ownership on operational performance. On the other hand, the number of banks with which the company maintains a relationship is positively conditioned by operational performance and negatively by managerial ownership. In turn, managerial ownership is negatively conditioned by operational performance and the nature of the banking relationship.
\end{abstract}

Keywords: nature of the banking relationship, managerial ownership, operational profitability, simultaneous effects

\section{Introduction}

In recent years small and medium enterprises (SMEs) have been the object of attention on the part of numerous works by virtue of their importance in terms of economic activity, job creation, innovation and ability to generate wealth in most economies (Behr et al., 2013). In market systems, issues of survival and the complexity and dynamism of the business environment require an increasingly deep understanding of organizations in general and SMEs in particular, as well as the variables or factors that are key to their performance. Particularly, in economies where bank financing is especially important in funding enterprises in general and SMEs specifically, understanding how the nature of the banking relationship may affect access to credit as well as its cost to SMEs, and hence their performance, as well as the reciprocal effects, without ignoring the role that managerial ownership may establish with those dimensions, is of particular importance for both business and for the conduct of economic and fiscal policy in those economies.

There is a significant literature that defends the role of banking supervision in solving the problems of adverse selection and moral hazard, especially experienced by SMEs, contributing either positively or negatively to their performance (e.g., Ongena and Smith, 2001, Chortareas et al., 2012, Yu et al., 2012, Barth et al., 2013). However, neither can it not be ignored that the nature of the established banking relations (bilateral vs. multilateral) is conditioned by a set of business features, among which performance (Detragiache et al., 2000, Farinha and Santos, 2002, Carletti, 2004) and managerial ownership (Stulz, 1988, Vilaseca, 2002) stand out.

Besides establishing close relationships with banks, SMEs are characterized by a substantial involvement of the equity holders in governing bodies, from which discretionary management rises with expected impacts on performance (Johnson et al., 2000, Dittmar and Mahrt-Smith, 2007). In turn, it cannot be forgotten that performance may induce involvement of managing bodies in the company's equity and leading to convergence of interests (Demsetz, 1983). Thus, the existing literature also does not fail to suggest relationships of reciprocal causality between managerial ownership and performance (e.g., Fama and Jensen, 1983b, Miguel et al., 2004), supporting the 
hypotheses of convergence of interests and expropriation as well as the adjustment made by the directors in their share of the equity relative to the profitability obtained (Mehran, 1995). Alongside a number of more recent studies (e.g., Chen et al., 2006, Yu et al., 2012) argues that under some circumstances the negative impact associated with the entrenchment of management on performance can be mitigated with greater monitoring and supervision on the part of the bank supervision and monitoring.

In this context, the integrated study of the nature of banking relationships, managerial ownership and operational performance is of particular importance in the context of SMEs, both due to the weight that the bank financing assumes for these companies, and to the specificities they contain in terms of information asymmetry, the value of the information produced and interests, which sometimes conflict, among the various business agents. Thus, the main goal of this study focuses on the integrated study of the nature of the banking relationship, managerial ownership and operational performance, as summarized in Figure 1.

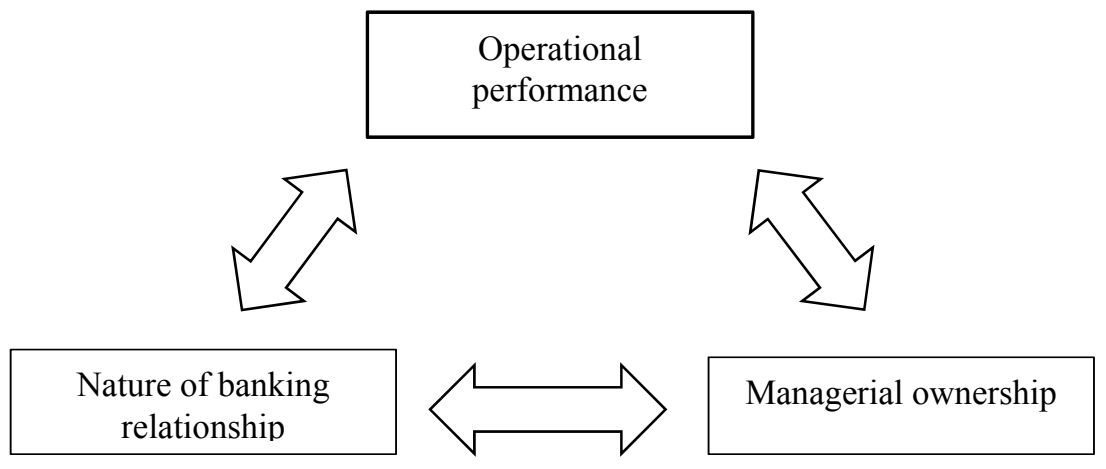

Figure 1. A conceptual framework

This paper is organized as follows: besides this introduction there are four additional sections. The second section is devoted to reviewing the relevant literature on the topic and formulating research hypotheses. The third section turns to the methodology. The fourth section presents the sample, the data and the indicators used to measure each of the attributes considered in this study. The authors present and discuss the results in the fifth section. Finally, the sixth section presents the main conclusions of this study.

\section{Theoretical Framework and Research Hypotheses}

\subsection{Nature of the Banking Relationship versus Performance}

The difficulties felt by SMEs in being financed combined with the scant possibility of access to capital markets, means that the credit market constitutes their main source of financing. The study of banking intermediation, therefore, gains particular relevance, especially when it comes to evaluating its contribution to SME performance (Boot, 2000).

The banking relationship is justified by imperfections which occur in financial markets and contributes significantly to their reduction. The legitimacy of financial intermediation arises from imperfections in these markets, namely: i) transaction costs, ii) information asymmetries and iii) agency costs (Ang et al., 2000, Drucker and Puri, 2009, Berger et al., 2010). Transaction costs result not only from expenses resulting from producing financial assets, stemming from the physical and temporal non-coincidence of interests on the part of the different agents involved, as well as costs relating to administrative processing and information acquisition, aspects which the financial intermediary performs with comparative advantages. As for the problems arising from information asymmetry, those generated $a$ priori, due to the difficulty in assessing the quality of credit applicants, should be distinguished from those which are a posteriori, resulting from the difficulty in controlling them. This second aspect relates to what the agency theory postulates. That is, the incentive that the company may have to behave opportunistically generates significant agency costs which the financial intermediary can reduce by supervision and control developed in the course and deepening of the relationship. Thus, firms subject to greater information asymmetry place particular importance on the nature of the relationships they establish with their creditors. As Diamond (1984) well recognizes, financial intermediation plays an important role in collecting information and reducing monitoring costs, as there is a strong incentive for financing through bank debt. The banks control the financing granted and supervise the company's activities through celebrating contracts and frequent interactions. In turn, bank loans signal the company's creditworthiness to other market agents and reduce information costs in concluding new contracts (Fama, 1985, Forte and Peña, 2011). 
Thus, the banking relationship provides benefits to stakeholders in the process insofar as it facilitates the exchange of information, grants greater negotiating flexibility, increases availability of credit and provision of services which best meet the needs of the company. Nevertheless, the banking relationship with a reduced, or at the limit with just one bank, also has associated disadvantages, particularly when the benefits of the relationship are not equally divided among the parties. These disadvantages arise from the appropriation of benefits either for the company - the soft budgeting problem, or for the bank - the hold-up problem.

In this context, the literature has looked into the effect that the nature of the banking relationship (bilateral vs. multilateral) may have on corporate performance and either positive or negative effects have been argued (Yu et al., 2012). To obtain credit, SMEs need to provide information to the financing institution, so that it will assess the investment to be financed. This information is often strategic in nature and disclosure may affect the company's competitiveness (Detragiache et al., 2000). In this sense, Yosha (1995) argues that firms with relevant information prefer to establish bilateral relations, where frequent interaction with a single stock or a very small number of banks is preferred so as to preserve confidentiality. Moreover, the economies of scale achieved by the bilateral banking relationship in the production of information, coupled with the fact that it is not easily transmissible, gives the bank holding the information the power to intervene in the company's management, ensuring greater availability of funds, providing a more favourable rate of interest and requiring less collateral and/or imposing fewer clauses in financing contracts (Petersen and Rajan, 1994). These aspects are particularly valued by smaller, younger and more opaque firms (with greater difficulty in demonstrating their true quality to outside investors), which rely almost exclusively on financing by bank credit.

Exclusivity of the banking relationship increases investment in informational reciprocity and reduces duplication of costs, thereby contributing to maximizing enterprise value (relationship hypothesis). However, the exclusive relationship confers monopoly power to the bank, possibly encouraging opportunistic behaviour (hold-up hypothesis). In turn, the multilateral relationship, reduces the hold-up problem, but also reduces incentives for intensifying the relationship. Among the actions that the company can develop to improve performance, maintaining continuity of the relationship with the financial institution is stressed. A small number of financial institutions or, in the extreme a single bank, allows information asymmetries and financing costs to be reduced and facilitates access to credit. However, there are also arguments pointing in the opposite direction: competition between the various credit institutions generates benefits in terms of availability and cost of credit. These benefits outweigh those arising from companies working with a reduced number of banks (Agarwal and Elston, 2001, Bris and Welch, 2005, Schenone, 2010). Nevertheless, companies will only be able to take advantage of this bank competition when it is effective and they have bargaining power. In this sense, Fok et al. (2004) provides empirical evidence that supports a negative relationship between the number of domestic banks companies work with and performance. Moreover, the financial constraints that SMEs may be subjected to cannot be ignored either. In many circumstances they initiate an adverse selection while seeking new resources, to the extent that the banks which are external to the relationship are unaware of the true risk and consider it too high, often refusing financing with respective impacts on performance. This situation particularly affects microenterprises.

Given the arguments that point to the nature of the banking relationship having either a positive or negative effect (bilateral versus multilateral) in operational performance, the following hypothesis is formulated:

\section{$\mathbf{H}_{1}$ : Banking relationships with a higher number of banks adversely affect SME operational performance.}

When studying the effect of the nature of the banking relationship (bilateral vs. multilateral), the effect of reciprocal causality cannot be ignored (Degryse and Ongena, 2001 Miguel et al., 2004, Fok et al., 2004). If, on the one hand, the concentration of banking relationships with a limited number of banks - and at the limit a single bank (bilateral relationship) - helps reduce the costs of information and prevents its disclosure to competitors, improving corporate performance; on the other, the relations established are conditioned by a set of business features among which performance stands out. Thus, banking relationships affect performance (Ongena and Smith, 2001) and this, in turn, the nature of those relationships (Yosha, 1995, Detragiache et al., 2000).

If there is reason to believe that the best performing companies prefer bilateral financing, thereby reducing the dissemination of confidential information to third parties (Yosha, 1995, Von Thadden, 1995), there are also arguments in the opposite direction. For example, Detragiache et al. (2000) and Carletti (2004) argue that firms with better performance and higher growth opportunities favour multilateral banking relationships so as to reduce liquidity risk. In this sense, the following hypothesis is formulated:

$\mathbf{H}_{2}$ : Operational performance positively affects the number of banks that SMEs have a relationship with. 


\subsection{Managerial Ownership versus Operational Performance}

The effect of managerial ownership on the company's operational performance has not garnered consensus in the existing literature. As prescribed by agency theory, the separation between ownership and control creates conflicts of interest between investors (owners and creditors) and directors, hence the need to develop internal and external control mechanisms able to coordinate them, given the difficulty of concluding complete contracts to resolve disparities (Baysinger and Hoskisson, 1990, Prowse, 1995). In this sense, Jensen and Meckling (1976) and Fama and Jensen (1983a) argue that a greater percentage of equity held by those in management positions enables an alignment of interests between managers and other owners with a positive effect on performance in reducing monitoring costs and the likelihood of suboptimal decisions (convergence of interests hypothesis). Nevertheless, high levels of managerial ownership may generate costs as mentioned by Fama and Jensen (1983b). Owning a substantial share of the equity gives the director the power to vote and/or significant influence. This may result in non-compliance with the objectives of maximizing value - expropriation hypothesis. Thus, high levels of managerial ownership can lead to problems of the management team's entrenchment and obtaining private benefits with negative impacts on performance (Schulze et al., 2001, Claessens et al., 2002, Miguel et al., 2004).

According to Berger et al. (1997), management entrenchment reflects the situation in which directors are immune to the discipline imposed by a wide range of control mechanisms. The level of entrenchment can be enhanced by several factors, emphasizing the weight of ownership held by the directors and their voting power in decision-making (Fama and Jensen, 1983b, Bebchuk et al., 2009). The opportunistic behaviour of directors, combined with a reduced likelihood of hostile takeover, makes them virtually immune to monitoring (Stulz, 1988).

In the case of SMEs where management is assumed by the actual owners, the interests of the principal and agent are aligned. However, when separation does exist, it creates strong incentives for the free-rider and entrenchment problems to arise on the part of family members in order to obtain private benefits, thereby negatively conditioning company performance. This situation is enhanced in the continental governance model (where the majority owner is a family industrial or financial group in nature). Conflicts of interest are thus higher than those found in the Anglo-Saxon model, where institutional investors (e.g., investment funds, pensions or insurance companies) show lower levels of conflict with the investee. Nevertheless, the problem of supervision remains, particularly in the presence of private information (Gedajlovic and Shapiro 1998, Franks and Mayer, 1998). Thus, the following hypothesis is formulated:

\section{$\mathbf{H}_{3}$ : Managerial ownership adversely affects operational performance.}

The ownership held by directors commonly arises from results generated by their decisions. Managerial ownership is thus often a reward granted to the director depending on corporate results (Mehran, 1995, Fernández Méndez et al., 2011). However, in the context of SMEs in general and in family businesses in particular, where there is only a slight separation between the private assets of the owners and those of the company, ownership concentration frequently leads to the controlling owner performing activities designed to extract private benefits (Shleifer and Vishny, 1997, La Porta et al., 2000). Performance, therefore, loses relevance as an inducer of greater participation of management in the company's equity and for convergence of interests as prescribed by agency theory (Shleifer and Vishny, 1997, La Porta et al., 2000). In this sense, some studies (e.g., Demsetz, 1983, Shleifer and Vishny, 1997) suggest that the controlling owners tend to defend their own interests by treating the company as a tool to provide employment for the family or as a way of financing it, limiting management positions to family members. Thus, family ties, the absence of a clear distinction between personal and corporate assets as well as the practices of expropriation, held by the controlling family and reduced professional management (allocation of management positions to household members) mean that operational performance does not constitute enough of an "attraction" to induce greater participation of the directors in corporate ownership (Anderson and Reeb, 2003, Arosa et al., 2010).

According this background, the following hypothesis is formulated:

\section{$\mathbf{H}_{4}$ : Operational performance negatively influences managerial ownership.}

\subsection{The Nature of the Banking Relationship versus Managerial Ownership}

The third dimension in the study relates to the relationships established between managerial ownership and the nature of banking relationships. In the previous paragraph our attention turned to the possible effect of managerial ownership on performance in the light of the convergence of interests and entrenchment hypotheses. To the extent that the ownership is shared by a larger number of owners, supervision and control acquire "public good" characteristics and the free-riding problem arises (Grossman and Hart, 1980, 1988, Demsetz, 1983), so that control rights should be concentrated in a small number of investors, the credit institution playing an important role in the daily management of the company. The exercise of supervision is relevant when the bank's stake becomes large 
enough to allow it to internalize corporate control costs and reduce agency problems, insofar as it acquires explicit control rights over noncompliant companies and ability to intervene in credit renewal. Simultaneously, the creditor's rights may not coincide with those of the other stakeholders conditioning wealth distribution. In the presence of imperfections in the market, resulting from asymmetric information, the credit institution may use its power to extract income, to the extent that it creates substitution costs, discouraging demand for alternative sources of financing. Management participation in the equity and the decisions taken by them can change the control exercised by creditors: if the initiative is valuable, excessive surveillance and control by the credit institution may trigger adverse consequences. In this sense, the following hypothesis is formulated:

$\mathbf{H}_{5}$ : Managerial ownership adversely affects the nature of the banking relationship.

As for the relationship between the nature of banking relationships and managerial ownership, it should be assessed bearing in mind the role that supervision of the banking system plays in reducing the costs associated with the management entrenchment, benefiting the relationship with the equity holders, to the extent this contributed to reducing private benefits and making investments with lower returns. In turn, insofar as the financial institution often interacts with the management team, it obtains privileged (confidential) information about the company's performance, reducing information asymmetries (Benston and Smith, 1976).

Thus, banking supervision is an important mechanism for reducing agency costs. Nevertheless, the objectives defined by the different stakeholders in the company's governance, do not always coincide. In this framework, the literature has sought to analyze them, bearing in mind the effect of asset substitution, advocated by Jensen and Meckling (1976). According to Diaz et al. (2004) banks, as lenders, do not participate in the benefits arising from a good corporate performance. The business agents, as owners, attempt to maximize the company's value, generating a conflict with credit institutions stemming from the conservative investment policy they impose when exercising control. In turn, as the directors intend to have a greater operational control over decisions which banks are predisposed to allow, they attempt to decrease dependency on the bank, subjecting themselves thereby to greater restrictions, either in quantity or price, than those they would be subject to with greater control of their activity. From this perspective, the literature (e.g., Jensen, 1986, DeAngelo et al., 2002) shifts agency conflicts to the relationship that is established between creditors and directors. Thus, the following hypothesis is formulated:

$\mathbf{H}_{\mathbf{6}}$ : The nature of the banking relationship adversely affects the managerial ownership.

\section{Methodology}

Given the objectives of this study and the hypotheses to be tested, the simultaneous equation model was formulated and is presented below:

Operational performance $=\beta_{10}+\beta_{11}$ Nature of the banking relationship $+\beta_{12}$ Managerial ownership + $\beta_{13}$ Size of the board $+\beta_{14}$ Reputation $+\beta_{15}$ Size of the company $+\beta_{16}$ Capital structure $+\varepsilon$

\section{Equation [1]}

Nature of the banking relationship $=\beta_{20}+\beta_{21}$ Operational performance $+\beta_{22}$ Managerial ownership + $\beta_{23}$ Nature of ownership $+\beta_{24}$ Size of the board $+\beta_{25}$ Reputation $+\beta_{26}$ Size of the company $+\beta_{27}$ Bank debt $+\beta_{28}$ Size of bank $+\varepsilon$

Equation [2]

Managerial ownership $=\beta_{30}+\beta_{31}$ Operational performance $+\beta_{32}$ Nature of the banking relationship + $\beta_{33}$ Capital dispersion of the company $+\beta_{34}$ Reputation $+\beta_{35}$ Size of the company $+\varepsilon$

Equation [3]

Considering the dimensions in this study (operational performance, nature of the banking relationship and managerial ownership), there is a set of characteristics inherent to the company, which cannot be ignored, susceptible to affecting these very dimensions. Notably among those are the following: the size of the board, reputation, size of the company, capital structure as well as bank debt, the nature of ownership, capital dispersion and size of the lending bank, among those which have received the greatest theoretical and empirical support in the existing literature.

The features of the board, particularly their size, have gained prominence in recent years both as a determinant of corporate performance, and the nature of the banking relationship. The influence of the size of the board on corporate performance is the result not only of its importance in the ownership structure, but also because it becomes a defining 
element of corporate decisions. The number of directors may interfere with the efficiency of supervision. While a greater number of directors facilitate the task of supervision, it also provides a greater variety of views (Tuggle et al. 2010, Johnson et al. 2013). Nevertheless, there are also those who argue that a greater number of directors raises problems of information coordination and flow throughout the decision-making process, thereby exerting a negative effect on operational performance (Boone et al., 2007, Kor and Sundaramurthy 2009, Menozzi et al., 2012).

The size of the board may be a mechanism capable of decreasing information asymmetries and increasing companies' bargaining power in establishing relationships with banks (Pearce and Zahra, 1992). If the number of directors is associated with the size of the company, as is usually the case, the largest benefit most from multilateral banking relationships (Bonfim et al., 2010). As highlighted by these authors, large companies have greater bargaining power in their relations with credit institutions. In addition to being subject to lower information asymmetries, it is easier for them to establish new banking relationships, compared to small and micro enterprises. Small and micro enterprises have greater difficulty in establishing new banking relationships by virtue of adverse selection and greater informational opacity they are subject to. The high risk they carry, supervision costs and required monitoring also inhibit establishing new banking relationships (Degryse et al., 2011). When these costs represent a significant weight relative to the size of the project to be financed, banks decline credit, preferring companies that provide economies of scale (Hernández-Cánovas and Martínez-Solano, 2007). In view of these arguments firm size is expected to have a positive effect on the number of banking relationships.

Firm size cannot be ignored either when studying the potential determinants of performance. If it is true that arguments are found pointing to a positive effect of this attribute on operational performance, sustained by economies of scale and reduced fixed costs (James and Timotthy, 2000, Orlitzky, 2001) and in diversifying the range of products (services) produced (rendered) (Lau et al., 2010, Yam et al., 2011), the fact remains that arguments can be found pointing in the opposite direction. In small and micro enterprises in particular, an individual or family, characterized by a reduced propensity to risk and very careful analysis of investments, simultaneously perform the role of owner and manager, possibly conditioning performance. On the other hand, this coincidence between ownership and management contribute to minimizing the agency costs of equity which naturally translates into a positive effect on these companies' performance (Andres, 2008).

When considering the firm size attribute, it is necessary to control its effect on ownership held those in management positions (directors) - managerial ownership. Demsetz (1983) underscores that as the company increases in scale, ownership tends to become more dispersed via a greater openness of equity and participation held by those in management positions (directors) tends to decrease. However, when we turn to SMEs, we must not forget that most of these companies are based on a family-type ownership structure; the family strongly resists relinquishing the position of steering the company's destiny. Nevertheless, as the business becomes more complex, difficulty in recruiting necessary efficient management capabilities from within the family becomes more evident (Górriz, 2002). Oftentimes, the family lacks the skills and capabilities required to keep direction in the hands of the family group. Thus, in these situations the reluctance of the family to relinquish control over the company's destiny will impose significant costs on the company (Shleifer and Vishny, 1997, La Porta et al., 1999). To overcome this constraint, the company recruits professional managers, who have no stake in the company's equity, to take control of the company's destiny. This line of argument also leads us to consider the size of the company and dispersion of its capital as potential determinants of managerial ownership.

Among the control variables considered in the model, company age is also highlighted as a determinant in the three study dimensions. According to Degryse and Van Cayseele (2000) and Sakai et al. (2010) company age reflects its reputation conveyed to the open market, constituting a valuable complement to private information that banks acquire during the relationship, facilitating, among other things, risk analysis by banks outside the relationship. In reflecting public information about the company's survival and maturity, it is an indicator that commitments have been met. Thus, it constitutes an intangible asset that is perceived by banks outside the relationship without incurring the high costs of collecting and processing information, contributing to increasing the number of banking relationships.

However, it is important to realize that companies, like people, have a finite life expectancy (Reis and Augusto, 2013). As such, on the one hand, age is maturity and experience with regards to the past; on the other, it also reflects the number of years that the company can expect to generate cash flows and results. Moreover, in the case of SMEs, age may also be associated with the generational effect resulting from generations who come after the founder being incorporated into the firm with the due effects both on performance and managerial ownership. With increasing age the probability that the company's ownership will be shared by an increasing number of individuals increases, as 
well as the conflicts that can arise if interests are not aligned. Oftentimes operational choices driven by personal preferences have effects which affect company performance (Sharmaa et al., 2007).

Fragmentation of ownership associated with the generational effect and potential conflicts of interest also has effects on managerial ownership. Management, provided by the founder in young companies and, having faced the problem of succession in older ones, is allocated among household members and professional managers with little or no equity participation (Villalonga and Amit, 2006, Barontini and Caprino, 2006). Thus, the potential negative effect that the company's age may exercise on managerial ownership cannot be ignored.

SMEs are faced with severe limitations when they require external financing. Its ownership structure, usually concentrated, is a serious impediment to issuing new equity, due to the reluctance of the current owners to share control of the company with new owners. Thus, given the strong constraints that SMEs face in access to external financing (either through new equity or through debt) its capital structure may be an important signaling vehicle in relation to the company's asset quality and its projects. It may thus constitute a differentiating element in corporate terms. However, let us not forget that the context of these companies, by virtue of the asymmetries they are subject to, sets them up for adverse selection and moral hazard problems, which naturally translates into higher credit cost and even rationing. This credit rationing, as Myers and Majluf (1984) point out, may make acceptance of value creating projects unviable. Even the viability of the company itself may come into question, with effects on operational profitability. Moreover, scarcity of equity gives it a very high debt structure, creating strong incentives in the banking system to interfere in day-to-day management decisions in the medium and long term, with impacts on operational performance (DeAngelo et al., 2002). In the face of these arguments, capital structure is considered a determinant on operational performance. However, the natural tendency of SMEs to overcome the credit constraints they face by increasing the number of banks with which they relates cannot be ignored, since the greater and more concentrated the debtor position, the greater the appetite for lenders to control business management (Hernández-Cánovas and Martínez-Solano, 2010). So, in order to control this possible behaviour, bank debt is included in the model as a determinant of the nature of the banking relationship.

Finally, the model also includes the nature of ownership and bank size as determinants of the number of bank relationships. Major owners, such as families in the context of SMEs, have two important effects on the nature of the banking relationship. On the one hand, as mentioned by Jensen and Meckling (1976), Fama and Jensen (1983b), Ortiz-Molina and Penas (2007) and Andres (2008), among others, in assuming a supervisory role, major owners significantly reduce information asymmetries and agency costs, facilitating an increase in the number of banking relationships. On the other hand, when these owners supply personal collateral, this facilitates new banking relationships (Ono and Uesugi, 2009, Steijvers and Voordeckers, 2009).

As highlight by Detragiache et al. (2000), the size of the bank, by virtue of the breadth of services rendered, can also constrain the nature of the banking relationship. Furthermore, smaller banks face increased difficulties when exposed to liquidity shocks, showing greater fragility, leading companies which are financed by these banks to establish multiple bank relationships (Detragiache et al., 2000). Thus, the size of the lending bank is expected to have a negative effect on the number of banking relationships.

\section{Sample, Data and Variables}

\subsection{Sample and Data}

Selecting SMEs as an object of study arises from the fact that they possess a set of particular characteristics, which separate them from others. Firstly, because in most cases they are unlisted companies, they face greater information problems when compared to larger enterprises. In smaller, normally younger, and more informationally opaque firms, the inability to credibly disclose their quality, associated with the tenuous separation between ownership and management, greatly increases information asymmetry between insiders and outsiders. Thus, the value of the banking relationship, based on reciprocity of soft information, is particularly relevant to the context of these companies. Secondly, SMEs are limited in obtaining external funds from financial institutions to the extent that the market is accessible only to large companies both, by virtue of transaction costs, and by the information asymmetries that small firms are exposed to. Thirdly, these firms are of particular importance in the fabric of most entrepreneurial economies, and Portugal is no exception. According to a study by the IAPMEI Planning and Studies Directorate in February 2008, SMEs represent $99.6 \%$ of the Portuguese business units, creating $75.2 \%$ of private employment and performing over half of all turnover (56.4\%) generating about 2.1 million jobs and over $€ 170.3$ billion turnover.

The study is carried out on a set of non-financial firms over the period from 2003 to 2007. The main source of information was the IBAS (Iberian Balances Analysis System version 33.1, update 110 - October 2008), which contains accounting and financial information on Portuguese and Spanish firms. Among the firms listed in the IBAS 
database: $i$ ) those without accounting information during the review period were eliminated, ii) only those that met the conditions set by the Bank of Portugal in their analyses (total assets, equity, turnover and positive GVA) were included, iii) those which were not economically viable, reflected by a positive operational profitability, were excluded $i v$ ) only those which met the conditions for SMEs to under Decree-Law No. 372/2007 (Note 1) were taken into account, $v$ ) all those where it was not possible to collect information on the number of credit institutions they work with were excluded, vi) companies in the financial sector were removed and, finally, vii ) only firms where capital distribution information was available were retained. Given these criteria, a final sample of 4,163 firms was reached.

Table 1 presents some characteristics of the companies in the sample: distribution of companies by number of employees, job creation and turnover by scaled number of employees. Analysis of this table indicates that $89 \%$ of the companies have fewer than 50 employees. Nevertheless, it is those with 10 or more workers that absorb $90 \%$ of the labour and have $83 \%$ of turnover. It is worth noting that a significant number of companies $(43 \%)$ have fewer than 10 employees, but their contribution to generate business and create value is of little importance (17\%). Regarding companies with 50 or more people, though their number is reduced (11\%), they absorb $45 \%$ of the workforce and account for $36 \%$ turnover.

Table 1. Sample: Main characteristics by class according to number of employees, average values 2003-2007

\begin{tabular}{lrrrrrrr}
\hline Variables & \multicolumn{1}{c}{ Total } & \multicolumn{2}{c}{ Less than 10} & \multicolumn{2}{c}{10 to 49} & \multicolumn{2}{c}{50 to 249} \\
\cline { 2 - 9 } & Value & Value & $\%$ & Value & $\%$ & Value & $\%$ \\
\hline Companies (No.) & 4,163 & 1,777 & 43 & 1,928 & 46 & 458 & 11 \\
Employees (No.) & 94,539 & 9,504 & 10 & 42,422 & 45 & 42,612 & 45 \\
Turnover (10 ${ }^{3}$ Eur) & $12,313,887$ & $2,037,058$ & 17 & $5,796,657$ & 47 & $4,480,172$ & 36 \\
\hline
\end{tabular}

\subsection{Variables}

Based on the literature, the indicators presented were selected to measure each of the attributes relevant to this study.

The corporate performance attribute is often assessed either by market indicators, either by accounting information. SMEs generally do not participate in the stock market, being financed primarily through bank intermediation. It therefore becomes particularly difficult to obtain information to allow assessment from a market prospective. Thus, those who study SMEs find themselves naturally compelled to resort to accounting information for the purpose of measuring this attribute. The following are among the most commonly used indicators: i) operational return on assets (ROA) (e.g., Castelli et al., 2012, Wang and Sarkis, 2013) and ii) return on equity (ROE) (e.g., Ding et al., 2012). With arguments found in the literature in mind, ROA was chosen. This choice is based on the fact that it allows the performance of total source of funds (internal or external) to be assessed and it is one of the best indicators for comparative analysis between companies. On the other hand, it determines financial survival in the long run and the ability to attract capital, either internally or externally. Joh (2003) even argues for the superiority of this indicator compared to those based on market information, stating that: $i$ ) stock price does not reflect the totality of information available in the absence of an efficient market values, $i i)$ there is empirical evidence that accounting profitability is more strongly associated with the firm's survival than Tobin's Q, and iii) it allows the performance of companies not traded in capital markets to be assessed. An additional advantage of this indicator stems from the fact that it is not directly influenced by the company's capital structure, largely expressing how the company makes use of its assets. According to what is unanimously accepted, this indicator is operationalized by dividing operational returns (OR) by total assets (TA).

To measure the nature of the banking relationship (bilateral vs. multilateral), the literature has relied primarily on three classes of indicators: number of banks, duration of the relationship and extent of services provided (e.g., Degryse and Ongena, 2001, Bris and Welch, 2005, Carletti et al., 2007). However, given the purpose of this study, we chose to use the number of banks with which the company works along the lines of Fok et al. (2004) and Yu et al. (2012). Managerial ownership is measured by the share of equity held by the board (Anderson and Reeb, 2003, Villalonga and Amit, 2006).

Regarding the nature of ownership, in particular the identity of the family versus non-family owner, in line with what is advocated by Ortiz-Molina and Peñas (2007), Andres (2008), among others, a dichotomous variable was chosen. It takes the value of 1 (one) when ownership held by the family is greater than $50 \%$, and the value of 0 (zero) otherwise. The capital dispersion attribute is measured by the number of participants in the company's capital/equity in accordance with Holderness (2003) and Thomsen (2005), among others. The size of the board attribute is evaluated 
by the number of directors in line with Linck et al., (2008), Brick and Chidambaran (2010) and Wintoki et al., (2012), among others. Business size has also been measured by a very broad set of indicators. For example, Degryse and Ongena (2001) and Bhagat and Bolton (2008) consider the logarithm of sales, Berger and Udell (1995), total net assets, Cardone et al. (2005), the number of employees. In our study business size is measured by the logarithm of total net assets as recommended by Petersen and Rajan (1994), De Bodt et al. (2005), and Andres (2008), among others. In accordance with Degryse and Van Cayseele (2000), and Sharmaa et al. (2007), among others, age was chosen to measure the company's reputation, i.e., the number of years since its establishment. Capital structure has also been measured by a wide range of indicators, which can be separated into two groups: one includes those that take into account total assets (application of resources) and the sources of funds; others focus only on the latter. In line with Fok et al. (2004) and Augusto et al. (2011), among others, our choice fell on one of the indicators included in the second group, i.e., the relationship between liabilities and equity. With regards to the bank debt, our choice fell on the ratio between the bank liabilities and total liabilities in line with Houston and James (2001). Finally, the bank size attribute can be measured by a number of indicators. Among these it is worth highlighting total assets of the credit institution, the amount of credit granted and the resources raised. Following Detragiache et al. (2000) and Haan and Poghosyan (2012) our choice fell on average value of assets of the banking institutions involved in the relationship.

Table 2 presents a summary of all of the indicators used and how they were operationalized.

Table 2. Attributes and indicators

\begin{tabular}{|c|c|c|}
\hline $\begin{array}{r}\begin{array}{c}\text { Endogenous } \\
\text { attributes }\end{array} \\
\end{array}$ & Indicator & Analytical Expression \\
\hline $\begin{array}{l}\text { Operational } \\
\text { performance }\end{array}$ & $\begin{array}{l}\text { Operational return on } \\
\text { assets }\end{array}$ & Operational returns / Assets \\
\hline $\begin{array}{l}\text { Nature of the } \\
\text { banking } \\
\text { relationship }\end{array}$ & Number of banks & Number of banks the company works with \\
\hline $\begin{array}{l}\text { Managerial } \\
\text { ownership }\end{array}$ & $\begin{array}{l}\text { Ownership held by those } \\
\text { in management positions } \\
\text { (directors) }\end{array}$ & $\begin{array}{l}\text { Ownership held by those in management positions } \\
\text { (directors)/ Total ownership }\end{array}$ \\
\hline $\begin{array}{r}\text { Exogenous } \\
\text { attributes }\end{array}$ & Indicator & Analytical Expression \\
\hline $\begin{array}{l}\text { Nature of } \\
\text { ownership }\end{array}$ & $\begin{array}{ll}\text { Family } \\
\text { Other }\end{array}$ & $\begin{array}{l}\text { Dichotomous variable that assumes the value of one if } \\
\text { at least } 50 \% \text { is owned by a family, otherwise it is zero }\end{array}$ \\
\hline Capital dispersion & Number of owners & Number of owners \\
\hline Size of board & Number of directors & Number of directors \\
\hline Business size & Asset logarithm & Natural logarithm of total net assets \\
\hline Reputation & Age & Number of years since founding \\
\hline Capital structure & Debt & Liabilities / Equity \\
\hline Bank debt & Bank debt & Bank liabilities / Liabilities \\
\hline Bank size & Bank assets & $\begin{array}{l}\text { Average value of assets of banks the company } \\
\text { maintains relationships with }\end{array}$ \\
\hline
\end{tabular}

\section{Results and Discussion}

Initially, the estimation of the simultaneous equations model is assessed in terms of its identification and structure, since this affects the estimation method to be adopted. The endogeneity of each dependent variable is assessed as well.

A simultaneous equations model is identified when estimating the parameters of each of its equations does not result from a combination of the remaining parameters. That is, the identification problem arises when different sets of structural coefficients are compatible with the same set of data. Evaluating the identification of a system of simultaneous equations can be gauged by the conditions of order and rank (Gujarati and Porter 2008). Given the condition of order each equation of the model is identified. Bearing in mind the structure of the model, the first equation excludes four variables, the second, two and the third, five (corresponding to the missing variables in each equation, but included in the others). To ensure the condition of rank, at least one non-zero determinant of order 1 must be obtained from the coefficients of the excluded variables in each equation, but included in the others. These 
coefficients may be chosen to form a determinant which is necessarily non-zero. Thus, from the general principles of identification, we have an identified system of equations. The two-stage least squares method (2SLS) is recommended for their estimation. Nevertheless, the three-stage least squares method (3SLS) yields more efficient estimates for the parameters than the two-stage method (2SLS) (Gujarati and Porter, 2008). The 3SLS method applies the GLS (Generalized Least Squares) methodology, an extension of two-stage least squares, to a system of equations which was estimated with the 2SLS method.

The use of the 3SLS estimation method involves the following steps: 1) the reduced system is estimated by the OLS (Ordinary Least Squares) method to obtain the estimated values of the endogenous variables; 2) the estimated values of the endogenous variables are substituted in the structural form of the system; then, the structural equations are estimated by the OLS method, and 3) the GLS method is applied to estimate the equations together (Pindyck and Rubinfeld, 2000). Because the 3SLS estimates the simultaneous equations jointly, it is more efficient than 2SLS, which is why this method has been adopted to estimate the proposed model.

With identification of the model assured, in a second phase, the endogenous dimensions are assessed. Given this goal each of the equations of the model was estimated individually using the method of ordinary least squares (Wooldridge, 2009). Considering the sample and the average values of the variables for the 2003-2007 period, Table 3 presents the results of the individual estimation of each equation. At a significance level of $5 \%$, the variables considered dependents in each equation appear as independents the remaining equations of the model. When the model was evaluated as a whole, the F statistic shows that, for a significance level of $1 \%$, the null hypothesis of the coefficients of the independent variables considered in each model is to be rejected. Through the Durbin-Watson test the lack of correlation between the residual random variables is analyzed, i.e., if their covariance is zero, $\mathrm{E}\left(\varepsilon_{\imath}, \varepsilon_{\varphi}\right)=0, \imath \neq \varphi$. Since the value of the test model is approximately $2(1,995,1,984,1,938$ for equation 1,2 and 3 , respectively) it was concluded that there was no autocorrelation between residues. When bias of the results is assessed by virtue of multicollinearity through the variance inflation factor (VIF), the highest values obtained were 1,664 (equation 1), 2,127 (equation 2) and 1,356 (equation 3), thus ensuring the absence of significant correlation between the independent variables.

Table 3. Endogeneity study - estimation results: ordinary least squares

\begin{tabular}{|c|c|c|c|c|c|c|c|c|c|}
\hline \multirow[b]{2}{*}{ Estimation } & \multicolumn{3}{|c|}{$\begin{array}{c}\text { Operational performance } \\
\text { [Equation 1] }\end{array}$} & \multicolumn{3}{|c|}{$\begin{array}{c}\text { Nature of the banking rel. } \\
\text { [Equation 2] }\end{array}$} & \multicolumn{3}{|c|}{$\begin{array}{c}\text { Managerial ownership } \\
\text { [Equation 3] }\end{array}$} \\
\hline & $\begin{array}{c}\text { Beta } \\
\text { Coeffic. }\end{array}$ & $\mathrm{t}$ & Sig. & $\begin{array}{c}\text { Beta } \\
\text { Coeffic. }\end{array}$ & $\mathrm{t}$ & Sig. & $\begin{array}{c}\text { Beta } \\
\text { Coeffic. }\end{array}$ & $\mathrm{t}$ & Sig. \\
\hline $\begin{array}{l}\text { Constant } \\
\text { Operational }\end{array}$ & 0.13064 & 23.420 & $* * *$ & -0.42293 & -3.197 & $* * *$ & 128.41 & 44.040 & $* * *$ \\
\hline performance & & & & -0.90604 & -3.045 & $* * *$ & -80.221 & -9.002 & $* * *$ \\
\hline Nature of banking rel. & -0.00458 & -5.847 & $* * *$ & & & & 2.2892 & 5.008 & $* * *$ \\
\hline Managerial ownership & -0.00021 & -8.011 & $* * *$ & 0.00165 & 2.549 & ** & & & \\
\hline Nature of ownership & & & & 0.19079 & 2.576 & $* *$ & & & \\
\hline Capital dispersion & & & & & & & -1.8227 & -4.477 & $* * *$ \\
\hline Size of board & 0.00184 & 3.841 & $* * *$ & 0.08471 & 8.863 & $* * *$ & & & \\
\hline Reputation & -0.00029 & -3.820 & $* * *$ & 0.01047 & 7.274 & $* * *$ & -0.1339 & -3.024 & $* * *$ \\
\hline Business size & -0.00370 & -4.527 & $* * *$ & 0.34451 & 22.83 & $* * *$ & -6.6479 & -15.200 & $* * *$ \\
\hline Capital structure & -0.00074 & -7.444 & $* * *$ & & & & & & \\
\hline Bank debt & & & & 1.16895 & 12.40 & $* * *$ & & & \\
\hline Bank size & & & & $-7.396 \mathrm{e}-09$ & -11.20 & $* * *$ & & & \\
\hline Adjusted R Square & 0.052 & & & 0.320 & & & 0.083 & & \\
\hline Durbin-Watson & 1.995 & & & 1.984 & & & 1.938 & & \\
\hline$F$ & 39.15 & & & 245.63 & & & 76.19 & & \\
\hline Sig. & 0.000 & & & 0.000 & & & 0.000 & & \\
\hline No. & 4,163 & & & 4,163 & & & 4,163 & & \\
\hline
\end{tabular}

*** Significant at the $1 \%$ level; ** Significant at the $5 \%$ level. 
The results obtained from the various estimations clearly indicate the existence of endogeneity between operational performance, the nature of the banking relationship and managerial ownership. The relationships established in the estimation of each equation, acquire increased justification when comprehensively interpreted in the context of a simultaneous equations model. Table 4 summarizes the results in the estimation of the simultaneous equations model formulated using the three-stage least squares method (3SLS).

Table 4. Results of simultaneous system

\begin{tabular}{|c|c|c|c|c|c|c|c|c|c|}
\hline \multirow[b]{2}{*}{ Estimation } & \multicolumn{3}{|c|}{$\begin{array}{c}\text { Operational performance } \\
\text { [Equation 1] }\end{array}$} & \multicolumn{3}{|c|}{$\begin{array}{l}\text { Nature of the banking rel. } \\
\text { [Equation 2] }\end{array}$} & \multicolumn{3}{|c|}{$\begin{array}{c}\text { Managerial ownership } \\
\text { [Equation 3] }\end{array}$} \\
\hline & $\begin{array}{c}\text { Coeffic. } \\
\text { Beta }\end{array}$ & $\mathrm{t}$ & Sig. & $\begin{array}{c}\text { Coeffic. } \\
\text { Beta }\end{array}$ & $\mathrm{t}$ & Sig. & $\begin{array}{l}\text { Coeffic. } \\
\text { Beta }\end{array}$ & $\mathrm{t}$ & Sig. \\
\hline $\begin{array}{l}\text { Constant } \\
\text { Operational }\end{array}$ & 0.19000 & 28.810 & $* * *$ & -1.5292 & -3.687 & $* * *$ & 221.190 & 27.620 & $* * *$ \\
\hline performance & & & & 7.43704 & 2.535 & $* *$ & -1128.83 & -17.570 & $* * *$ \\
\hline Nature of banking rel. & -0.01152 & -4.013 & $* * *$ & & & & -11.4981 & -3.429 & $* * *$ \\
\hline Managerial ownership & -0.00085 & -31.360 & $* * *$ & -0.00769 & -2.512 & $* *$ & & & \\
\hline Nature of ownership & & & & 1.16246 & 4.652 & $* * *$ & & & \\
\hline Capital dispersion & & & & & & & -0.49662 & -1.247 & \\
\hline Size of board & 0.00015 & 0.468 & & 0.09476 & 8.875 & $* * *$ & & & \\
\hline Reputation & -0.00018 & -2.081 & $* *$ & 0.01166 & 6.864 & $* * *$ & -0.21403 & -2.299 & $* *$ \\
\hline Business size & -0.00309 & -2.103 & $* *$ & 0.37028 & 19.17 & $* * *$ & -4.24785 & -2.659 & $* * *$ \\
\hline Capital structure & $-4.783 e^{-05}$ & -0.717 & & & & & & & \\
\hline Bank debt & & & & 1.58488 & 8.752 & $* * *$ & & & \\
\hline Bank size & & & & $-7.535 \mathrm{e}^{-09}$ & -10.940 & $* * *$ & & & \\
\hline
\end{tabular}

*** Significant at the $1 \%$ level; ** Significant at the $5 \%$ level.

The results clearly show the existence of simultaneity between operational performance, the nature of the banking relationship and managerial ownership expressed by the significance obtained for each variable in the estimation of the remaining variables $(\alpha=5 \%)$.

The simultaneous equations model not only allows us to analyze the interdependent relationships between operational performance, the nature of the banking relationship and managerial ownership, but it also allows us to test the causal relationships that have been cited in the literature, between the independent variables and the endogenous variables in each equation. Interpretation of the results will be done at two levels: one regarding interdependent relationships established between the endogenous variables, and the other regarding the effect of the control variables included in each of the equations in the endogenous variables.

\section{i) Nature of the banking relationship versus operational performance}

The first dimension under study takes into account the interdependent relations between the nature of the banking relationship and operational performance. The results (see Table 4) show an inverse relationship between the number of banks which the company works with (nature of the banking relationship) and operational performance and a positive effect of the operational performance on nature of the banking relationship. These results suggest that operational performance facilitates relationships with financial institutions, supporting the hypothesis $\mathrm{H}_{2}$.

Increasing the number of banks has a negative impact on operational performance, suggesting that a closer banking relationship is associated with better operational performance. In addition to supporting hypothesis $\mathrm{H}_{1}$, this negative effect of the number of banks on operational performance finds support in the literature often evidenced by the following argument: the intensification of the relationship allows greater mutual knowledge, contributing to a reduction in information asymmetries, characterized by the fact that credit applicants possess private and exclusive information, which is difficult to transfer out of the relationship (Castelli et al., 2012). Maintaining and consolidating a banking relationship with a small number of entities allows adverse selection and moral hazard to be reduced (Abbring et al., 2003). Under these circumstances the lender bank can practice differentiated active interest rates and, in short, adjusted credit agreements according to risk level. It can also require a priori interest rates and less 
collateral, as well as less restrictive clauses in drafting contracts, as advocated by Jiménez et al. (2006), Berger et al. (2011a) and Berger et al. (2011b), among others.

Consolidating the relationship allows the credit institution to track the set of corrective actions initiated by the company during/after periods of financial difficulties - screening/monitoring (Berger and Udell, 2006, De la Torre et al., 2010). Thus, intensifying the banking relationship is shown to be an important competitive advantage for both parties: for the bank, to the extent that it appropriates private information which it accumulates over the course of the relationship, reducing information asymmetry; for the financed company, which, due to reduced information asymmetries, sees improvements in the medium term in contractual conditions, both in terms of price, and in terms of the amount of credit with effects positive on its financial and operational performance. These results are in line what has been advocated by Agarwal and Hauswald (2010) and Bharath et al. (2011). Moreover, Hernández-Cánovas and Martinez-Solano (2006) while studying Spanish SMEs concluded that interacting with a smaller number of banks they obtain funds at a lower cost. They also note that financial institutions show a clear tendency to increase the requirement for personal guarantees as the relationship progresses. In showing a negative effect of the number of banking relationships on operational performance, our results are also in line with Ongena and Degryse (2001) and Farinha and Santos (2002); contrary, however, to Agarwal and Elston (2001) and Weinstein and Yafeh (1998), among others.

The results provide further support for a positive effect of operational performance on the number of banks the company works with. To the extent the company improves its performance, the number of banking relationships increases simultaneously. Companies improve their bargaining power and, in anticipation of hold-up problems, are encouraged to establish new relationships. These results corroborate the findings of Farinha and Santos (2002). For them, Portuguese companies with high revenues increase the number of bank relationships to minimize hold-up costs. In the same vein, Detragiache et al. (2000) and Carletti (2004) argue that firms with better performance and greater growth opportunities prefer multilateral relations so as to reduce liquidity risk.

\section{ii) Managerial ownership versus operational performance}

The results validate the hypothesis of simultaneity between managerial ownership and operational profitability expressed by the statistical significance of the estimators obtained. Analysis of the results shows that managerial ownership and the operational profitability have an inverse relationship.

These results validate hypothesis $\mathrm{H}_{3}$ and are in line with those obtained by Schulze et al. (2001) and Gompers et al. (2010) and Zerni et al. (2010), among others, who reported that increased managerial ownership gives rise to entrenchment and provides directors with secure jobs and privileges that can harm corporate profitability. These results differ, however, from those obtained by Margaritis and Psillaki (2010) and Drakos and Bekiris (2010), whose results support the convergence of interests hypothesis, whereby the propensity of the director to comply with maximizing company value is directly proportional to ownership.

Analysis of the results also shows that operational performance establishes an inverse relationship with managerial ownership, validating hypothesis $\mathrm{H}_{4}$. The family nature that is an assumed feature of a significant number of companies in our sample leads to their control providing sufficient non-pecuniary benefits, such that profitability does not constitute, in itself, a sufficient motivator for the owner's participation in management. In companies with high levels of family control, decisions are less scrutinized, without public vote, and the decision to allocate benefits to family members may not be constrained by profitability as documented by Schulze et al. $(2001,2002)$ and Arosa et al. (2010). Furthermore, in small businesses controlled by their owners, profitability is not a strong enough incentive for management to participate in the company's capital (Stewart et al., 2001). Schulze et al. (2001) and Chu (2011) suggest that the agency costs incurred by small businesses are related to the altruistic feelings of the owners as family management, constituting a strong incentive to promote and sustain family ties. Our results are in line with those obtained by Schulze et al. (2001) and Steier (2003); however, they contradict those reported by Littuen (2000) and Chung and Chan (2012) who found performance had a positive effect on managerial ownership. It is worth noting that this positive effect of performance on managerial ownership is particularly valid in the context of large firms, as shown by Anderson and Reeb (2003) and Bhagat and Bolton (2008).

\section{iii) Nature of the banking relationship versus managerial ownership}

According to the results the nature of the banking relationship and managerial ownership has an inverse relationship. The role played by managerial ownership in the nature of banking relationships is found to be significant and negative, validating hypothesis $\mathrm{H}_{5}$. Strengthening the director's participation in the company's capital can increase 
the costs of supervision and control that together with lack of transparency makes them virtually immune to oversight, making establishing new relationships difficult.

The negative effect of the nature of the banking relationship on managerial ownership, while validating hypothesis $\mathrm{H}_{6}$, provides the empirical arguments supporting that creditors exercise their control prioritizing low risk projects of. As underscored by Yu et al. (2012), when directors are not properly aligned with business objectives, they are not interested in an intense external supervision, preferring relationships with a large number of credit institutions.

As for the second level of analysis (the effect of the control variables on the endogenous variables), the results of the estimation of the model provide support for most of the effect of the control variables considered. The results show that all independent variables that have a statistically significant effect on the representative variables of each equation, except for 'size of the board' and 'capital structure' as determinants of operational profitability, and 'capital dispersion' were not shown to be significant with regards to managerial ownership.

Although the size of the board was not shown to be a determinant of corporate performance, our results support the hypothesis that a higher number of directors adds to the company's ability to establish new banking relationships. A higher number of directors are normally associated with company size. Larger firms have greater bargaining power, are subject to smaller asymmetries and generate economies of scale for financing banks (Hernández-Cánovas and Martínez-Solano, 2010). Thus, it is possible for them to benefit from multilateral banking relationships. Our results confirm this line of argument as they also show that firm size has a positive effect on the number of bank relationships. This attribute is found to be determinant regarding operational performance and managerial ownership. The results support an inverse effect of firm size both on its operational performance and managerial ownership. These results provide support for the argument that SMEs in general, and micro-enterprises in particular, experience the simultaneous role of the owner and manager by the same person or a limited number of people, where the line that separates personal from company assets is very tenuous. This circumstance leads them to be more cautious in considering their operational and strategic decisions, gearing up for maximizing value and minimizing operational and financial risk, as Riahi-Belkaoui (1998) also concludes. Moreover, the greater coincidence between owner and manager, a feature of small and micro enterprises, also contributes to minimizing the agency costs of equity. However, as these companies grow and become more complex it becomes more difficult to find the necessary/required management capabilities within their set of owners. This situation leads them to resort to professional managers under penalty of facing the consequences of keeping shareholders exercising management positions for which they do not meet the necessary skills or capabilities, in line with what Shleifer and Vishny (1997) and Peng and Jiang (2010) concluded. Our results both corroborate this negative effect that firm size has on ownership held by whoever performs management functions, and show the negative effect expected from the dispersion of capital in managerial ownership.

Company age, an indicator used to measure reputation is determinant of three dimensions under study. The negative effect of age on operational performance supports the thesis that companies do not have an infinite life expectancy. According to this line of argument, company age reflects the number of years that it can expect to produce results: the higher that number, the fewer years it will have to generate results. In turn, the positive effect of age on the number of banking relationships corroborates the thesis that age is an indicator of corporate reputation and that commitments are respected, as advocated in previous studies, such as Detragiache et al. (2000), Hernández-Cánovas and Martinez-Solano (2010), and Sakai et al. (2010). The negative effect of this attribute on managerial ownership is consistent with the line of argument which holds that for older companies exposed to problems of succession, management is shared among family members or professional directors with a reduced stake in the company's equity (Barontini and Caprino, 2006).

In line with Detragiache et al. (2000) and arguments that have stated that the credit constraints that SMEs face lead them to seek new banking relationships when their bank debt increases. Our results provide support for a direct relationship between these two variables. Nevertheless, this demand for new banking relationships is also often motivated by the size of the financing bank that naturally limits its range of services: the higher this is, the less companies need to seek new relationships, as shown by our results.

Finally, our results also support the positive effect of the nature of ownership on the number of bank relationships. Families with a high percentage of capital exert effective control over the company, particularly when the primary owner, or one of its members, plays a major role on the board (Chu, 2011, Chung and Chan, 2012). These circumstances give the family business advantages in reducing opportunistic behaviour and supervision costs, thereby facilitating the number of banking relationships. 
Until now the industry effect was absent from our analysis. In order to capture this possible effect, industry dummies were introduced into the model. The endogeneity between corporate performance, the nature of the banking relationship and managerial ownership is assured (see Table 5), confirming the results shown in Table 6 that the statistical significance of the variables does not change, as well as its effect. The estimated values are shown to be very similar to those obtained in Table 4 , suggesting that the industry effect does not alter the relationship between the nature of banking relationships, managerial ownership and operational performance.

Table 5. Endogeneity study - estimation results (ordinary least squares): industry effect

\begin{tabular}{|c|c|c|c|c|c|c|c|c|c|}
\hline \multirow[b]{2}{*}{ Estimation } & \multicolumn{3}{|c|}{$\begin{array}{c}\text { Operational performance } \\
\text { [Equation 1] }\end{array}$} & \multicolumn{3}{|c|}{$\begin{array}{l}\text { Nature of the banking rel. } \\
\text { [Equation 2] }\end{array}$} & \multicolumn{3}{|c|}{$\begin{array}{c}\text { Managerial ownership } \\
\text { [Equation 3] }\end{array}$} \\
\hline & $\begin{array}{c}\text { Coeffic. } \\
\text { Beta }\end{array}$ & $\mathrm{t}$ & Sig. & $\begin{array}{c}\text { Coeffic. } \\
\text { Beta }\end{array}$ & $\mathrm{t}$ & Sig. & $\begin{array}{l}\text { Coeffic. } \\
\text { Beta }\end{array}$ & $\mathrm{t}$ & Sig. \\
\hline $\begin{array}{l}\text { Constant } \\
\text { Operational }\end{array}$ & 0.17154 & 17.200 & $* * *$ & -0.41251 & -1.954 & $*$ & 107.659 & 18.270 & $* * *$ \\
\hline performance & & & & -0.76699 & -2.543 & ** & -69.425 & -7.709 & $* * *$ \\
\hline Nature of banking rel. & -0.00412 & -5.311 & $* * *$ & & & & 2.089 & 4.587 & $* * *$ \\
\hline Managerial ownership & -0.00019 & -6.968 & $* * *$ & 0.00166 & 2.554 & ** & & & \\
\hline Nature of ownership & & & & 0.14812 & 2.001 & ** & & & \\
\hline Capital dispersion & & & & & & & -1.795 & -4.390 & $* * *$ \\
\hline Size of board & 0.00140 & 2.859 & $* * *$ & 0.08076 & 8.193 & $* * *$ & & & \\
\hline Reputation & -0.00026 & -3.392 & $* * *$ & 0.01044 & 7.208 & $* * *$ & -0.143 & -3.218 & $* * *$ \\
\hline Business size & -0.00315 & -3.846 & $* * *$ & 0.34032 & 22.210 & $* * *$ & -6.646 & -15.190 & $* * *$ \\
\hline Capital structure & -0.0007 & -7.298 & $* * *$ & & & & & & \\
\hline Bank debt & & & & 1.1888 & 12.58 & *** & & & \\
\hline Bank size & & & & $-7.3713 \mathrm{e}^{-9}$ & -11.16 & $* * *$ & & & \\
\hline Industry Dummies & $\mathrm{Yg}$ & & & Yes: & & & & & \\
\hline
\end{tabular}

*** Significant at the $1 \%$ level; ** Significant at the 5\% level; * Significant at the $10 \%$ level.

Table 6. Result of simultaneous system - industry effect

\begin{tabular}{|c|c|c|c|c|c|c|c|c|c|}
\hline \multirow[b]{2}{*}{ Estimation } & \multicolumn{3}{|c|}{$\begin{array}{c}\text { Operational performance } \\
\text { [Equation 1] }\end{array}$} & \multicolumn{3}{|c|}{$\begin{array}{l}\text { Nature of the banking } \\
\text { relationship } \\
\text { [Equation 2] }\end{array}$} & \multicolumn{3}{|c|}{$\begin{array}{l}\text { Managerial ownership } \\
\text { [Equation 3] }\end{array}$} \\
\hline & $\begin{array}{c}\text { Coeffic. } \\
\text { Beta }\end{array}$ & $\mathrm{t}$ & Sig. & $\begin{array}{c}\text { Coeffic. } \\
\text { Beta }\end{array}$ & $\mathrm{t}$ & Sig. & $\begin{array}{c}\text { Coeffic. } \\
\text { Beta }\end{array}$ & $\mathrm{t}$ & Sig. \\
\hline $\begin{array}{l}\text { Constant } \\
\text { Operational }\end{array}$ & 0.21830 & 19.370 & $* * *$ & -1.7959 & -3.120 & $* * *$ & 255.366 & 17.300 & $* * *$ \\
\hline performance & & & & 7.09080 & 2.320 & $* *$ & -1114.29 & -17.320 & $* * *$ \\
\hline Nature of banking rel. & -0.01343 & -4.679 & $* * *$ & & & & -14.1667 & -4.149 & *** \\
\hline Managerial ownership & -0.00084 & -32.680 & $* * *$ & -0.00925 & -2.906 & $* * *$ & & & \\
\hline Nature of ownership & & & & 1.14914 & 4.503 & $* * *$ & & & \\
\hline Capital dispersion & & & & & & & -0.4715 & -1.221 & \\
\hline Size of board & 0.00010 & 0.342 & & 0.09240 & 8.363 & $* * *$ & & & \\
\hline Reputation & -0.00015 & -1.700 & $*$ & 0.01107 & 6.554 & $* * *$ & -0.1764 & -1.872 & * \\
\hline Business size & -0.00202 & -1.381 & $* * *$ & 0.35374 & 18.920 & $* * *$ & -2.94749 & -1.816 & * \\
\hline Capital structure & $-4.0472 \mathrm{e}^{-5}$ & -0.6236 & & & & & & & \\
\hline Bank debt & & & & 1.61642 & 8.517 & $* * *$ & & & \\
\hline Bank size & & & & $-7.4221 \mathrm{e}^{-9}$ & -10.560 & $* * *$ & & & \\
\hline Industry Dummies & $\mathrm{Ye}$ & & & $\mathrm{Ye}$ & & & $Y$ & & \\
\hline
\end{tabular}

*** Significant at the $1 \%$ level; ** Significant at the $5 \%$ level; * Significant at the $10 \%$ level. 


\section{Conclusion}

From a sample of 4,163 SMEs and cross-section data, this study provides additional empirical evidence on the integrated study of the nature of the banking relationship, managerial ownership and operational performance. This issue is of particular importance for small companies, given the role the banking system plays in funding and monitoring their activities, their specificities in terms of information asymmetry and conflicts of interest arising between investors owners and creditors) and directors. Moreover, our empirical analysis focuses on Portuguese SMEs, an economy where these companies represent over $99.5 \%$ of business units and where the banking system is a reference stakeholder.

We began our study contemplating performance and nature of banking relationships, checking if their number conditions operational profitability and if this in turn affects the number of relationships, establishing reciprocity between them. The results provide support for theories that claim SMEs can improve their performance while deepening their relations with their main financing bank to the extent that it finds additional incentives to monitor the company's activity and streamline the process of renegotiating debt. However, when the operational performance of companies improves, there are strong incentives to establish new relationships insofar as they contribute to reducing hold-up costs. Given the results concerning the control variables, our results suggest that, on the one hand, age and size of the company are inhibitors of performance; on the other, they show that the nature of ownership, managerial ownership, size of the board, age, business size and bank debt foster establishing new relationships while size of the financing/funding institution is an obstacle.

When we turn to the inter-relationship between performance and managerial ownership, it appears they have a negative relationship. The results suggest that greater involvement of the directors in corporate ownership induces their entrenchment with negative impact on operational performance. This, in turn, does not constitute a sufficient incentive for greater involvement on the part of the owner in managing the business, with the consequent limited scrutiny decisions are subject to and the ease with which private benefits are attributed. The results also show that managerial ownership decreases as companies gain size and maturity.

Taking the integrated study of the inner nature of the ownership and banking relationships into account, our results show that these two dimensions have an inverse relationship, meaning that strengthening participation of directors in business ownership makes the banking supervision mechanism less relevant, if not actually hindering it. In turn, when the control exercised by the credit institutions on operational activity is higher than management is predisposed to allow, it faces increased difficulties.

In recognizing that information asymmetries are particularly intense for SMEs and the specificity that agency costs assume within these companies, the integrated study of the nature of banking relationships, managerial ownership and operational performance becomes particularly relevant. In our view, this study, then, takes a step forward in the state of the art in this field.

\section{References}

Abbring, H., Chiappori A., Heckman, J., \& Pinquet, J. (2003). Adverse selection and moral hazard in insurance: Can dynamic data help to distinguish? Journal of the European Economic Association, 1(2/3), 512-521. http://dx.doi.org/10.1162/154247603322391152

Agarwal, R., \& Elston, J. (2001). Bank-firm relationships, financing and firm performance in Germany. Economics Letters, 72(2), 225-232. http://dx.doi.org/10.1016/S0165-1765(01)00427-X

Agarwal, S., \& Hauswald, R. (2010). Distance and private information in lending. Review of Financial Studies, 23(7), 2757-2788. http://dx.doi.org/10.1093/rfs/hhq001

Anderson, C., \& Reeb, M. (2003). Founding-family ownership, corporate diversification, and firm leverage. Journal of Law and Economics, 46(2), 653-684. http://dx.doi.org/10.1086/377115

Andres, C. (2008). Large shareholders and firm performance: An empirical examination of founding-family ownership. Journal of Corporate Finance, 14(4), 431-445. http://dx.doi.org/10.1016/j.jcorpfin.2008.05.003

Ang, J., Cole, R., \& Lin, J. (2000). Agency costs and ownership structure. The Journal of Finance, 55(1), 81-106. http://dx.doi.org/10.1111/0022-1082.00201

Arosa, B., Iturralde, T., \& Maseda, A. (2010). Ownership structure and firm performance in non-listed firms: Evidence from Spain. Journal of Family Business Strategy, 1(2), 88-96. http://dx.doi.org/10.1016/j.jfbs.2010.03.001 
Augusto, M. G., Lisboa, J. V., \& Brandão, E. F. (2011). Dividend policy and capital structure: An empirical application in the Portuguese corporate context. International Journal of Decision Sciences, Risk and Management, 3(1/2), 2-31.

Barontini, R., \& Caprio, L. (2006). The effect of family control on firm value and performance: Evidence from continental Europe. European Financial Management, $12(5), \quad 689-723$. http://dx.doi.org/10.1111/j.1468-036X.2006.00273.x

Barth, J., Lin, C., Ma, Y., Seade, J., \& Song, F. (2013). Do bank regulation, supervision and monitoring enhance or impede bank efficiency? Journal of Banking \& Finance, 27(8), 2879-2892. http://dx.doi.org/10.1016/j.jbankfin.2013.04.030

Baysinger, B., \& Hoskisson, R.E. (1990). The composition of boards of directors and strategic control: Effects on corporate strategy. Academy of Management Review, 15(1), 72-87. http://dx.doi.org/10.5465/AMR.1990.4308231

Bebchuk, L., Cohen, A., \& Ferrell, A. (2009). What matters in corporate governance? Review of Financial Studies, 22(2), 783-827. http://dx.doi.org/10.1093/rfs/hhn099

Behr, P., Norden, L., \& Noth, F. (2013). Financial constraints of private firms and bank behavior. Journal of Banking \& Finance, 37(9), 3472-3485. http://dx.doi.org/10.1016/j.jbankfin.2013.05.018

Benston, J., \& Smith, Jr. (1976). A transactions cost approach to the theory of financial Intermediation. The Journal of Finance, 31(2), 215-231. http://dx.doi.org/10.1111/j.1540-6261.1976.tb01882.x

Berger, A. N., \& Udell, G. F. (1995). Relationship lending and lines of credit in small firm finance. Journal of Business, 68(3), 351-381. http://dx.doi.org/10.1086/296668

Berger, A. N., \& Udell, G. F. (2006). A more complete conceptual framework for SME finance. Journal of Banking \& Finance, 30(11), 2945-2966. http://dx.doi.org/10.1016/j.jbankfin.2006.05.008

Berger, A., Frame, W., \& Ioannidou, V. (2011b). Tests of ex ante versus ex post theories of collateral using private and public information. Journal of Financial Economics, 100(1), 85-97. http://dx.doi.org/10.1016/j.jfineco.2010.10.014

Berger, A., Hasan, I., \& Zhou, M. (2010). The effects of focus versus diversification on bank performance: Evidence from Chinese banks. Journal of Banking \& Finance, 34(7), 1417-1435. http://dx.doi.org/10.1016/j.jbankfin.2010.01.010

Berger, N., Espinosa-Vega, A., Frame, S., \& Miller, H. (2011a). Why do borrowers pledge collateral? New empirical evidence on the role of asymmetric information. Journal of Financial Intermediation, 20(1), 55-70. http://dx.doi.org/10.1016/j.jfi.2010.01.001

Berger, P. G., Ofek, E., \& Yermack, D. L. (1997). Managerial entrenchment and capital structure decisions. The Journal of Finance, 52(4), 1411-1438. http://dx.doi.org/10.1111/j.1540-6261.1997.tb01115.x

Bhagat, S., \& Bolton, B. (2008). Corporate governance and firm performance. Journal of Corporate Governance, 14(3), 257-273. http://dx.doi.org/10.1016/j.jcorpfin.2008.03.006

Bharath, T., Dahiya, S., Saunders, A., \& Srinivasan, A. (2011). Lending relationships and loan contract terms. Review of Financial Studies, 24(4), 1141-1203. http://dx.doi.org/10.1093/rfs/hhp064

Bonfim, D., Dai, Q., \& Franco, F. (2010). Relações bancárias e custos de financiamento, Relatório de estabilidade financeira, Banco de Portugal, 163-180.

Boone, C., Field, M., Karpoff, J., \& Raheja, G. (2007). The determinants of corporate board size and composition: An empirical analysis. Journal of Financial Economics, 85(1), 66-101. http://dx.doi.org/10.1016/j.jfineco.2006.05.004

Boot, A. (2000). Relationship banking: What do we know? Journal of Financial Intermediation, 9(1), 7-25. http://dx.doi.org/10.1006/jfin.2000.0282

Brick, I., \& Chidambaran, N. (2010). Board meetings, committee structure, and firm value. Journal of Corporate Finance, 16(4), 533-553. http://dx.doi.org/10.1016/j.jcorpfin.2010.06.003

Bris, A., \& Welch, I. (2005). The optimal concentration of creditors. The Journal of Finance, 60(5), 2193-2212. http://dx.doi.org/10.1111/j.1540-6261.2005.00796.x 
Cardone, C., Casasola, M. J., \& Samartin, M. (2005). Do banking relationships improve credit conditions for Spanish SMEs? Universidad Carlos III de Madrid, Working Paper 05-28.

Carletti, E. (2004). The structure of bank relationships, endogenous monitoring and loan rates. Journal of Financial Intermediation, 13(1), 58-86. http://dx.doi.org/10.1016/j.jfi.2003.04.001

Carletti, E., Cerasi, V., \& Daltung, S. (2007). Multiple-bank lending: Diversification and free- riding in monitoring. Journal of Financial Intermediation, 16(3), 425-451. http://dx.doi.org/10.1016/j.jfi.2007.03.001

Castelli, A., Dwyer, P., \& Hasan, I. (2012). Bank relationships and firms' financial performance: The Italian experience. European Financial $\quad$ Management, http://dx.doi.org/10.1111/j.1468-036X.2009.00531.x

Chen, R., Guo, W., \& Mande, V. (2006). Corporate value, managerial stockholdings and investments of Japanese firms. Journal of International Financial Management \& Accounting, 17(1), 29-51. http://dx.doi.org/10.1111/j.1467-646X.2006.00120.x

Chortareas, G., Girardone, C., \& Ventouri, A. (2012). Bank supervision, regulation, and efficiency: Evidence from the European Union. Journal of Financial Stability, 8(4), 292-302. http://dx.doi.org/10.1016/j.jfs.2011.12.001

Chu, W. (2011). Family ownership and firm performance: Influence of family management, family control, and firm size. Asia Pacific Journal of Management, 28(4), 833-851. http://dx.doi.org/10.1007/s10490-009-9180-1

Chung, M., \& Chan, T. (2012). Ownership structure, family leadership, and performance of affiliate firms in large family business groups. Asia Pacific Journal of Management, 29(2), 303-329. http://dx.doi.org/10.1007/s10490-011-9281-5

Claessens, S., Djankov, S., Fan, J. P., \& Lang, L. H. (2002). Disentangling the incentive and entrenchment effects of large shareholding. The Journal of Finance, 57(6), 2741-2771. http://dx.doi.org/10.1111/1540-6261.00511

De Bodt, E., Lobez, F., \& Statnik, J. C. (2005). Credit rationing, customer relationship and the number of banks: An empirical analysis. European Financial Management, 11(2), 195-228. http://dx.doi.org/10.1111/j.1354-7798.2005.00282.x

De la Torre, A., Martínez, S., \& Schmukler, L. (2010). Bank involvement with SMEs: beyond relationship lending. Journal of Banking \& Finance, 34(9), 2280-2293. http://dx.doi.org/10.1016/j.jbankfin.2010.02.014

DeAngelo, H., DeAngelo, L., \& Wruck, K.H. (2002). Asset liquidity, debt covenants, and managerial discretion in financial distress: The collapse of L.A. Gear. Journal of Financial Economics, 64(1), 3-34. http://dx.doi.org/10.1016/S0304-405X(02)00069-7

Degryse, H., Masschelein, N., \& Mitchell, J. (2011). Staying, dropping, or switching: The impacts of bank mergers on small firms. The Review of Financial Studies, 24(4), 1102-1140. http://dx.doi.org/10.1093/rfs/hhp126

Degryse, H., \& Ongena, S. (2001). Bank relationships and firm profitability. Financial Management, 30(1), 9-34. http://dx.doi.org/10.2307/3666389

Degryse, H., \& Van Cayseele, P. (2000). Relationship lending within a bank-based system: Evidence from European small business data. Journal of Financial Intermediation, 9(1), 90-109. http://dx.doi.org/10.1006/jfin.1999.0278

Demsetz, H. (1983). The structure of ownership and the theory of the firm. Journal of Law and Economics, 26(2), 375-390. http://dx.doi.org/10.1086/467041

Detragiache, E., Garella, P., \& Guiso, L. (2000). Multiple versus single banking relationships: Theory and evidence. The Journal of Finance, 55(3), 1133-1161. http://dx.doi.org/10.1111/0022-1082.00243

Diamond, D. (1984). Financial intermediation and delegated monitoring. Review of Economic Studies, 51(3), 393-414. http://dx.doi.org/10.2307/2297430

Diaz, B., Olalla, M., \& Azofra, S. (2004). Bank acquisitions and performance: Evidence from a panel of European credit entities. Journal of Economics and Business, 56(5), 377-404. http://dx.doi.org/10.1016/j.jeconbus.2004.02.001

Ding, H., Cai, J., \& Niu, Y. (2012). Correlations between executive pay, equity incentive and corporate performance: Empirical analysis based on panel data of China's listed companies. International Journal of Financial Research, 3(3), 24-31. http://dx.doi.org/10.5430/ijfr.v3n3p24 
Dittmar, A., \& Mahrt-Smith, J. (2007). Corporate governance and the value of cash holdings. Journal of Financial Economics, 83(3), 599-634. http://dx.doi.org/10.1016/j.jfineco.2005.12.006

Drakos, A., \& Bekiris, V. (2010). Corporate performance, managerial ownership and endogeneity: A simultaneous equations analysis for the Athens stock exchange. Research in International Business and Finance, 24(1), 24-38. http://dx.doi.org/10.1016/j.ribaf.2009.01.002

Drucker, S., \& Puri, M. (2009). On loan sales, loan contracting, and lending relationships. Review of Financial Studies, 22(7), 2835-2872. http://dx.doi.org/10.1093/rfs/hhn067

Fama, E. (1985). What's different about banks? Journal of Monetary Economics, 15(1): 29-39. http://dx.doi.org/10.1016/0304-3932(85)90051-0

Fama, E., \& Jensen, M. C. (1983a). Agency problems and residual claims. Journal of Law and Economics, 26(2), 327-349. http://dx.doi.org/10.1086/467038

Fama, E., \& Jensen, M. C. (1983b). Separation of ownership and control. Journal of Law and Economics, 26(2), 301-325. http://dx.doi.org/10.1086/467037

Farinha, L.A., \& Santos, J.A.C. (2002). Switching from single to multiple bank lending relationships: Determinants and implications. Journal of Financial Intermediation, 11(2), 124-151. http://dx.doi.org/10.1006/jfin.2001.0328

Fernández Méndez, C., Arrondo García, R., \& Fernández Rodríguez, E. (2011). Corporate governance and executive pay in the Spanish market. The Spanish Review of Financial Economics, 9(2), 55-68. http://dx.doi.org/10.1016/j.srfe.2011.09.004

Fok, W., Chang, C., \& Lee, T. (2004). Bank relationships and their effects on firm performance around the Asian financial crisis: Evidence from Taiwan. Financial Management, 33(2), 78-89.

Forte, S., \& Peña, J. I. (2011). Debt refinancing and credit risk. The Spanish Review of Financial Economics, 9(1), 1-10. http://dx.doi.org/10.1016/j.srfe.2010.10.001

Franks, J., \& Mayer, C. (1998). Bank control, takeovers and corporate governance in Germany. Journal of Banking \& Finance, 22(10/11), 1385-1403. http://dx.doi.org/10.1016/S0378-4266(98)00060-0

Gedajlovic, E. R., \& Shapiro, D. M. (1998). Management and ownership effects: Evidence from five countries. Strategic Management Journal, $\quad 19(6), \quad 533-553$. http://dx.doi.org/10.1002/(SICI)1097-0266(199806)19:6<533::AID-SMJ957>3.0.CO;2-\#

Gompers, A., Ishii, J., \& Metrick, A. (2010). Extreme governance: An analysis of dual-class firms in the United States. Review of Financial Studies, 23(3), 1051-88. http://dx.doi.org/10.1093/rfs/hhp024

Górriz, C.G. (2002). Propiedad y gobierno: La empresa familiar. Revista Vasca de Economía Ekonomizar, 50(2), 158-181.

Grossman, S. J., \& Hart, O. D. (1988). One share-one vote and the market for corporate control. Journal of Financial Economics, 20, 175-202. http://dx.doi.org/10.1016/0304-405X(88)90044-X

Grossman, S.J., \& Hart, O.D. (1980). Takeover bids, the free-rider problem, and the theory of the corporation. The Bell Journal of Economics, 11(1), 42-64. http://dx.doi.org/10.2307/3003400

Gujarati, D., \& Porter, D. (2008). Basic econometrics (5th ed.). McGraw Hill.

Haan, J., \& Poghosyan, T. (2012). Bank size, market concentration, and bank earnings volatility in the US. Journal of International Financial Markets, Institutions and Money, 22(1), 35-54. http://dx.doi.org/10.1016/j.intfin.2011.07.002

Hernández-Cánovas, G., \& Martínez-Solano, P. (2006). Banking relationships: Effects on debt terms for small Spanish firms. Journal of Small Business Management, 44(3), 315-333. http://dx.doi.org/10.1111/j.1540-627X.2006.00174.x

Hernández-Cánovas, G., \& Martinez-Solano, P. (2007). Effect of the number of banking relationships on credit availability: Evidence from panel data of Spanish small firms, Small Business Economics, 28(1), 37-53. http://dx.doi.org/10.1007/s11187-005-6704-z

Hernández-Cánovas, G., \& Martínez-Solano, P. (2010). Relationship lending and SME financing in the continental European bank-based system. Small Business Economics, 34(4), 465-482. http://dx.doi.org/10.1007/s11187-008-9129-7 
Holderness, C. (2003). A survey of blockholders and corporate control. Economic Policy Review, 9(1), 51-64.

Houston, J.F., \& James, C.M. (2001). Do relationships have limits? Banking relationships, financial constraints, and investment. Journal of Business, 74(3), 347-74. http://dx.doi.org/10.1086/321930

James, W., \& Timotthy, P. (2000). Internationalization of small firms: An examination of export competitive patterns, firm size, and export performance. Journal of Small Business Management, 38(2), 34-47.

Jensen, M. C. (1986). Agency costs of free cash flow, corporate finance, and takeovers. American Economic Review, $76(2), 323-329$.

Jensen, M.C., \& Meckling, W.H. (1976). Theory of the firm: Managerial behaviour, agency cost and ownership structure. Journal of Financal Economics, 3(4), 305-360. http://dx.doi.org/10.1016/0304-405X(76)90026-X

Jiménez, G., Salas, V., \& Saurina, J. (2006). Determinants of collateral. Journal of Financial Economics, 81(2), 255-281. http://dx.doi.org/10.1016/j.jfineco.2005.06.003

Joh, S. (2003). Corporate governance and firm profitability: Evidence from Korea before the economic crisis. Journal of Financial Economics, 68(2), 287-322. http://dx.doi.org/10.1016/S0304-405X(03)00068-0

Johnson, S., Boone, P., Breach, A., \& Friedman, E. (2000). Corporate governance in the Asian financial crisis. Journal of Financial Economics, 58(1/2), 141-186. http://dx.doi.org/10.1016/S0304-405X(00)00069-6

Johnson, S., Schnatterly, K., \& Hill, A. (2013). Board composition beyond independence: social capital, human capital, and demographics. Journal of Management, 39(1), 232-262. http://dx.doi.org/10.1177/0149206312463938

Kor, Y., \& Sundaramurthy, C. (2009). Experience-based human capital and social capital of outside directors. Journal of Management, 35(4), 981-1006. http://dx.doi.org/10.1177/0149206308321551

La Porta, R., López-de-Silanes, F., Shleifer, A., \& Vishny, R. (1999). The quality of government. Journal of Law, Economics and Organization, 15(1), 222-279. http://dx.doi.org/10.1093/jleo/15.1.222

La Porta, R., López-de-Silanes, F., Shleifer, A., \& Vishny, R. (2000). Agency problems and dividend policies around the world. The Journal of Finance, 55(1), 1-33. http://dx.doi.org/10.1111/0022-1082.00199

Lau, A., Tang, E., \& Yam, R. (2010). Effects of supplier and customer integration on product innovation and performance: Empirical evidence in Hong Kong manufacturers. Journal of Product Innovation Management, 27(5), 761-777. http://dx.doi.org/10.1111/j.1540-5885.2010.00749.x

Linck, J., Netter, J., \& Tina, Y.T. (2008). The determinants of board structure. Journal of Financial Economics, 87(2), 308-328. (DOI: 10.1016/j.jfineco.2007.03.004)

Littuen, H. (2000). Entrepreneurship and the characteristics of the entrepreneurial Personality. International Journal of Entrepreneurial Behavior and Research, 6(6), 295-309. http://dx.doi.org/10.1108/13552550010362741

Margaritis, D., \& Psillaki, M. (2010). Capital structure, equity ownership and firm performance. Journal of Banking \& Finance, 33(3), 621-632. http://dx.doi.org/10.1016/j.jbankfin.2009.08.023

Mehran, H. (1995). Executive compensation structure, ownership, and firm performance. Journal of Financial Economics, 38(2), 163-184. http://dx.doi.org/10.1016/0304-405X(94)00809-F

Menozzi, A., Urtiaga, M., \& Vannoni, D. (2012). Board composition, political connections, and performance in state-owned enterprises. Industrial and Corporate Change, 21(3), 671-698. http://dx.doi.org/10.1093/icc/dtr055

Miguel, A., Pindado, J., \& Torre, L. (2004). Ownership structure and firm value: new evidence from the Spanish corporate governance system. Strategic Management Journal, 25(12), 1199-1207. http://dx.doi.org/10.1002/smj.430

Myers, S., \& Majluf, N. (1984). Corporate financing and investment decisions when firms have information that investors do not have. Journal of Financial Economics, 13(2), 187-221. http://dx.doi.org/10.1016/0304-405X(84)90023-0

Ongena, S., \& Smith, D. (2001). The duration of bank relationships. Journal of Financial Economics, 61(3), 449-475. http://dx.doi.org/10.1016/S0304-405X(01)00069-1

Ono, A., \& Uesugi, I. (2009). Role of collateral and personal guarantees in relationship lending: Evidence from Japan's SME loan market. Journal of Money, Credit and Banking, 41(5), 935-960. http://dx.doi.org/10.1111/j.1538-4616.2009.00239.x 
Orlitzky, M. (2001). Does firm size confound the relationship between corporate social performance and firm financial performance? Journal of Business Ethics, 33(2), 167-180. http://dx.doi.org/10.1023/A:1017516826427

Ortiz-Molina, H., \& Penas, M.F. (2007). Lending to small businesses: The role of loan maturity in addressing information problems. Small Business Economics, 30(4), 361-383. http://dx.doi.org/10.1007/s11187-007-9053-2

Pearce, J. A., \& Zahra, S. A. (1992). Board compensation from a strategic contingency perspective. Journal of Management Studies, 29(4), 411-438. http://dx.doi.org/10.1111/j.1467-6486.1992.tb00672.x

Peng, W., \& Jiang, Y. (2010). Institutions behind family ownership and control in large firms. Journal of Management Studies, 47(2), 253-273. http://dx.doi.org/10.1111/j.1467-6486.2009.00890.x

Petersen, M., \& Rajan, R. (1994). The benefits of lending relationship: Evidence from small business data. The Journal of Finance, 49(1), 3-37. http://dx.doi.org/10.1111/j.1540-6261.1994.tb04418.x

Pindyck, R., \& Rubinfelg, D. (2000). Econometric Models and Economic Forecasts (4th ed.). McGRAW-HILL International editions.

Prowse, S. (1995). Corporate governance in an international perspective. A survey of corporate control mechanisms among large firms in the US, UK, Japan and Germany. Financial Market, Institutions and Instruments, 4(1), $1-63$.

Reis, P., \& Augusto, M. (2013). Business mortality table: The average of life expectancy as a fundamental instrument in calculation of the terminal or continuing value in enterprise valuation. Proceedings of $3^{\text {rd }}$ International Network of Business and Management Journals (INBAM), 17-19, June, Lisbon, Portugal. (22 p.).

Riahi-Belkaoui, A. (1998). The effects of the degree of internationalization on firm performance. International Business Review, 7(3), 315-321. http://dx.doi.org/10.1016/S0969-5931(98)00013-4

Sakai, K., Uesugi, I., \& Watanabe, T. (2010). Firm age and the evolution of borrowing costs: Evidence from Japanese small firms. Journal of Banking \& Finance, 34(8), 1970-1981. http://dx.doi.org/10.1016/j.jbankfin.2010.01.001

Schenone, C. (2010). Lending relationships and information rents: Do banks exploit their information advantages? Review of Financial Studies, 23(3), 1149-1199. http://dx.doi.org/10.1093/rfs/hhp080

Schulze, W., Lubatkin, M., \& Dino, R. (2002). Altruism, agency, and competitiveness of family firms. Managerial and Decision Economics, 23(4/5), 247-259. http://dx.doi.org/10.1002/mde.1064

Schulze, W., Lubatkin, M., Dino, R., \& Buchholtz, A. (2001). Agency relationship in family firms: Theory and evidence. Organization Science, 12(2), 99-116. http://dx.doi.org/10.1287/orsc.12.2.99.10114

Sharmaa, P., Hoyb, F., Astrachanc, J., \& Koiranen, M. (2007). The practice-driven evolution of family business educacion. Journal of Business Research, 60(10), 1012-1021. http://dx.doi.org/10.1016/j.jbusres.2006.12.010

Shleifer, A., \& Vishny, R. (1997). A survey of corporate governance. The Journal of Finance, 52(2), 737-783. http://dx.doi.org/10.1111/j.1540-6261.1997.tb04820.x

Steier, L. (2003). Variants of agency contracts in family-financed ventures as a continuum of familial altruistic and market rationalities. Journal of Business Venturing, 15(5), 597-618. http://dx.doi.org/10.1016/S0883-9026(03)00012-0

Steijvers, T., \& Voordeckers, W. (2009). Collateral and credit rationing: A review of recent empirical studies a guide for future research. Journal of Economic Surveys, 23(5), 924-946. http://dx.doi.org/10.1111/j.1467-6419.2009.00587.x

Stewart, Jr., Wayne, H., \& Philip, L. (2001). Risk propensity differences between entrepreneurs and managers: A meta-analytic review. Journal of Applied Psychology, 86(1), 145-153. http://dx.doi.org/10.1037/0021-9010.86.1.145

Stulz, R. (1988). Managerial control of voting rights: Financial policies and the market for corporate control. Journal of Financial Economics, 20, 25-54. http://dx.doi.org/10.1016/0304-405X(88)90039-6

Thomsen, S. (2005). Conflicts of interest or aligned incentives? Block-holder ownership, dividends and firm value in the US and the EU. European Business Organization Law Review, 6, 201-225. http://dx.doi.org/10.1017/S1566752905002016 
Tuggle, C., Schnatterly, K., \& Johnson, R. (2010). Attention patterns in the boardroom: how board composition and processes affect discussion of entrepreneurial issues. Academy of Management Journal, 53(3), 550-571. http://dx.doi.org/10.5465/AMJ.2010.51468687

Vilaseca, A. (2002). The shareholder role in the family business: Conflict of interests and objectives between nonemployee shareholders and top management team. Family Business Review, 15(4), 299-321. http://dx.doi.org/10.1111/j.1741-6248.2002.00299.x

Villalonga, B., \& Amit, R. (2006). How do family ownership, control and management affect firm value? Journal of Financial Economics, 80(2), 385-418. http://dx.doi.org/10.1016/j.jfineco.2004.12.005

Von Thadden, E.L. (1995). Long-term contracts, short-term investment and monitoring. Review of Economic Studies, 62(4), 557-575. http://dx.doi.org/10.2307/2298077

Wang, Z., \& Sarkis, J. (2013). Investigating the relationship of sustainable supply chain management with corporate financial performance. International Journal of Productivity and Performance Management, 62(8), 871-888. http://dx.doi.org/10.1108/IJPPM-03-2013-0033

Weinstein, D. E., \& Yafeh, Y. (1998). On the costs of a bank-centred financial system: Evidence from the changing main bank relations in Japan. The Journal of Finance, 53(2), 635-672. http://dx.doi.org/10.1111/0022-1082.254893

Wintoki, M., Linck, J., \& Netter, J. (2012). Endogeneity and the dynamics of internal corporate governance. Journal of Financial Economics, 105(3), 581-606. http://dx.doi.org/10.1016/j.jfineco.2012.03.005

Wooldridge, J. (2009). Introductory Econometrics: A Modern Approach (4th ed.).

Yam, R., Lo, W., Tang, E., \& Lau, A. (2011). Analysis of sources of innovation, technological innovation capabilities, and performance: An empirical study of Hong Kong manufacturing industries. Research Policy, 40(3), 391-402. http://dx.doi.org/10.1016/j.respol.2010.10.013

Yosha, O. (1995). Information disclosure costs and the choice of financing source. Journal of Financial Intermediation, 4(1), 3-20. http://dx.doi.org/10.1006/jfin.1995.1001

Yu, H., Sopranzetti, B., \& Lee, C. (2012). Multiple banking relationships, managerial ownership concentration, and firm value: A simultaneous equation approach. The Quarterly Review of Economics and Finance, 52(3), 286-297. http://dx.doi.org/10.1016/j.qref.2012.07.002

Zerni, M., Kallunki, P., \& Nilsson, H. (2010). The Entrenchment problem, corporate governance mechanisms, and firm value. Contemporary Accounting Research, 27(4), 1169-1206. http://dx.doi.org/10.1111/j.1911-3846.2010.01043.x

Note

Note 1. Defines micro, small and medium businesses. The category of micro, small and medium enterprises is made up of enterprises which employ fewer than 250 persons and whose annual turnover does not exceed $€ 50$ million or whose total annual balance sheet does not exceed $€ 43$ million. A small business is defined as an enterprise which employs fewer than 50 persons and whose annual turnover or total annual balance sheet does not exceed $€ 10$ million. A micro enterprise is defined by employing less than 10 persons and whose annual turnover does not exceed $€ 2$ million. 